\title{
KOMPARASI MEDIA PEMBELAJARAN KOKAMI DAN MEDIA ULAR TANGGA MENGGUNAKAN MODEL PEMBELAJARAN LANGSUNG PADA MATERI STRUKTUR ATOM TERHADAP HASIL BELAJAR SISWA KELAS X SMA NEGERI 5 AMBON
}

\author{
Imarsih Ninkeula', Y. T. Filindity ${ }^{1}$, dan Y. H. Dulanlebit ${ }^{1}$ \\ ${ }^{1}$ Departement of Chemistry-FKIP, Pattimura University Ambon \\ Diterima 10 Februari 2019/Disetujui 12 Maret 2019
}

\begin{abstract}
Comparative study of learning media of mysterious card box with the media of snake ladder on the material of atomic structure to the result of study of class $X$ student of SMA N 5 AMBON. The mysterious card learning media box is applied to the $X$ class $M I A_{1}$ and the ladder snake media in the $X$ class of $M I A_{3}$. From the results, the mysterious card learning media box can improve student learning outcomes, seen from the presentation of the achievement of the final test results obtained by the two classes, where the two classes have a presentation of different final result qualification ie qualification completed for class $\mathrm{X}-\mathrm{MI} \mathrm{A}_{1}$ which uses the mysterious card box learning medium is $100 \%$, and no qualifying fails with an average rating of 85.68 . But for the class $\mathrm{X}-\mathrm{MIA}$ using the learning media of snake ladder with qualified thoroughly is $51.51 \%$ and qualification failed $48.49 \%$ with an average value of 72.95, therefore Mann Whitney test results using SPSS 20 obtained a significance value of $0.002(>0.05)$ thus $\mathrm{H} 0$ is rejected and $\mathrm{H} 1$ is received so it can be concluded that there are differences in student learning outcomes using the mysterious box learning media and learning media snake ladder.
\end{abstract}

Keywords: Learning Media Kokami, Learning Media Snake Ladder, Learning Outcomes

\begin{abstract}
ABSTRAK
Telah dilakukan penelitian komparasi media pembelajaran kotak kartu misterius dengan media ular tangga pada materi struktur atom terhadap hasil belajar siswa kelas X SMA N 5 AMBON. Media pembelajaran kotak kartu misterius di terapkan pada siswa kelas $X \mathrm{MIA}_{1}$ dan media ular tangga pada kelas $\mathrm{X} M I \mathrm{~A}_{3}$. Dari hasil, media pembelajaran kotak kartu misterius dapat meningkatkan hasil belajar siswa, dilihat dari persentasi pencapaian hasil tes akhir yang diperoleh di kedua kelas, di mana kedua kelas memiliki persentasi kualifikasi hasil terakhir yang berbeda yakni kualifikasi tuntas untuk kelas $\mathrm{X}_{\mathrm{M}} \mathrm{MIA}_{1}$ yang menggunakan media pembelajaran kotak kartu misterius adalah $100 \%$, dan tidak terdapat siswa yang gagal dengan nilai rata-rata 85,68 . Sedangkan untuk kelas $\mathrm{X}-\mathrm{MIA}_{3}$ yang menggunakan media pembelajaran ular tangga dengan kualifikasi tuntas $51,51 \%$ dan kualifikasi gagal 48,49\% dengan nilai rata-rata 72,95, dan dari data hasil uji Mann Whitney menggunakan SPSS 20 diperoleh nilai signifikansi 0,002 $(>0,05)$. Dengan demikian maka $\mathrm{H}_{0}$ ditolak dan $\mathrm{H}_{1}$ diterima sehingga dapat disimpulkan terdapat perbedaan hasil belajar siswa menggunakan media pembelajaran kotak kartu misterius dan media pembelajaran ular tangga.
\end{abstract}

Kata Kunci: Media Pembelajaran Kokami, Media Pembelajaran Ular Tangga, Hasil Belajar.

\section{PENDAHULUAN}

Kemajuan pendidikan sangat berpengaruh terhadap kemajuan dan kualitas sumber daya manusia. Kurikulum 2013 menekankan pada sistem pembelajaran berbasis kompetensi yang menempatkan peserta didik untuk mampu merencanakan, menggali, menginterpretasi dan mengevaluasi hasilnya sendiri (Ketut,2013:38). Salah satu pembelajaran yang terintegrasi dengan 
pembelajaran sains yaitu kimia, yang bertujuan untuk mengembangkan kompetensi peserta didik. Kompetensi ini perlu dikembangkan agar peserta didik mampu memahami konsep-konsep kimia secara sistematis melalui pengalaman belajar yang lebih mendalam, mata pelajaran kimia merupakan mata pelajaran yang dianggap sulit untuk dipahami oleh siswa. Sebagian besar proses pembelajaran di sekolah diarahkan pada kemampuan siswa untuk mengingat berbagai informasi tanpa dituntut untuk memahami informasi yang diingatnya dan menghubungkan dengan kehidupan sehari-hari, akibatnya ketika siswa lulus dari sekolah hanya pintar secara teori tetapi miskin aplikasi (Sanjaya,2006:21).

Berdasarkan observasi di SMA Negeri 5 Ambon pada tahun ajaran 2015/2016 diketahui bahwa materi kimia dalam proses pembelajaran masih dianggap sulit. Hal ini disebabkan karena kegiatan pembelajaranmasih bersifat satu arah, siswa hanya melihat dan mendengar materi yang dijelaskan, kemudian harus bisa mengerjakan tugas yang diberikan guru. Hal ini kemudian memicu timbulnya rasa kurang minat dan menurunnya motivasi siswa dalam mengikuti pembelajaran kimia, akibatnya berpengaruh pada hasil belajar siswa. Salah satu cara untuk memecahkan masalah ini adalah dengan menerapkan media. Hamalik 1986 pada buku Arsyad Azhar mengemukakan bahwa pemakaian media pembelajaran dalam proses pembelajaran dapat membangkitkan keinginan dan minat belajar. Konsep struktur atom mempunyai banyak karakteristik, karena memiliki banyak sub konsep pembelajaran, untuk itu dalam proses pembelajaran dibutuhkan media yang dapat memotivasi siswa dalam belajar.

Salah satu media pembelajaran yang menyenangkan dan efektif dalam pembelajaran kimia adalah dengan menggunakan media permainan. Mediapermainan bertujuan untuk mengurangi kemonotonan dalam pembelajaran dan untuk menciptakan suasana pembelajaran yang menyenangkan. Media pembelajaran yang dipakai pada penelitian ini adalah Kokami (kotak kartu misterius) dan ular tangga.Kokami merupakan suatu permainan yang dapat dijadikan media pembelajaran, kokami ini terdiri dari sebuah kotak yang di dalamnya berisi kartu pesan. Dikatakan misterius karena isi di kartu tersebut tidak dapat diketahui sebelum amplop dibuka dan diketahui isi dari kartu tersebut. Penelitian terdahulu oleh Istiqomah febrian., dkk (2016) pada SMP Negeri 32 Semarang tentang pengaruh media kokami terhadap keterampilan berpikir kreatif dan aktivitas belajar tema bahan kimia yang menyimpulkan bahwa Media Kokami yang digunakan dalam penelitian berpengaruh kuat terhadap keterampilan berpikir kreatif siswa dengan $\mathrm{rb}=0,632$, dan juga berpengaruh sedang terhadap aktivitas belajar siswa dengan $\mathrm{rb}=0,522$.

Permainan selanjutnya yang dipakai dalam penelitian ini adalah permainan ular tangga. Ular tangga merupakan salah satu bentuk permainan yang merakyat dan digemari dari usia anak-anak, remaja, bahkan dewasa, selain itu media permainan ular tangga sangat efektif dalam proses pembelajaran, ular tangga dalam penelitian ini didesain menggunakan kartu yang berisi soal materi struktur atom serta menampilkan gambar-gambar yang berhubungan dengan kimia sehingga terlihat lebih menarik(Pramita Amilia dan Agustini Rudiana,2016: 17). Penelitian terdahulu oleh Pramita Amilia dan Agustini Rudiana (2016) tentang pengembangan media permainan ular tangga pada materi senyawa hidrokarbon kelas XI SMA untuk meningkatkan pemahaman konsep disimpulkan bahwa permainan ular tangga pada materi senyawa hidrokarbon layak digunakan sebagai media Hal ini ditunjukkan dengan data persentase validasi isi sebesar $85 \%$, validasi konstruk sebesar $93 \%$, kepraktisan permainan ular tangga berdasarkan angket respon siswa dengan persentase rata-rata sebesar 93\% efektivitas berdasarkan pemahaman konsep siswa dengan skor gain rata-rata $\geq 0,7$ dengan kategori tinggi dan $83 \%$ siswa tuntas secara klasikal.

Berdasarkan latar belakang di atas maka penulis tertarik untuk mengadakan penelitian dengan judulKomparasi Media Pembelajaran Kokami dan Ular Tangga Menggunakan Model Pembelajaran Langsung pada Materi Struktur Atom terhadap Hasil Belajar Siswa Kelas X SMA Negeri 5 Ambon. 


\section{METODE PENELITIAN}

\section{A. Tipe Penelitian}

Penelitian ini menggunakan metode eksperimen dengan rancangan penelitian pre Experiment Design (Arikunto, 2010:123), terdapat 2 kelas yaitu kelas Eksperimen 1 dan kelas Eksprimen II, dimana pada kelas Eksperimen I diajarkan dengan menggunakan model pembelajaran langsung dilengkapi dengan kokami (kotak kartu misterius), sedangkan kelas Eksperimen II diajarkan dengan menggunakan model pembelajaran langsung dilengkapi dengan media Ular tangga.

\section{B. Lokasi dan Waktu Penelitian}

Penelitian ini dilaksanakan pada SMA Negeri 5 Ambon, dari 4 september 2017 sampai dengan 22 september 2017.

\section{Populasi dan Sampel Penelitian}

1. Populasi penelitian adalah siswa kelas X SMA Negeri 5 Ambon tahun ajaran 2016-2017

2. Sampel diambil dengan teknik cluster random sampling sehingga diperoleh kelas $X-M I A_{1}$ sebagai kelas eksperimen I dengan jumlah siswa 33 orang dan kelas $\mathrm{X}-\mathrm{MIA}_{2}$ eksperimen II dengan jumlah siswa 33 orang.

\section{Variabel Penelitian}

1. Variabel dependen (bebas)

2. Variabel Independen (terikat)

\section{E. Instrumen Penelitian}

Instrumen yang digunakan dalam penelitian ini adalah

1. Instrumen tes

a. Tesawal (pre-test),

b. Teakhir (post test)

2. Instrumen non test
a. Observasi
b. Lembar kerja siswa

\section{F. Teknik Pengumpulan Data}

Adapun teknik pengumpulan data dalam penelitian ini adalah menggunakan teknik tes. Tes merupakan cara yang digunakan dalam rangka pengukuran dan penelaian di bidang pendidikan (Sudjono, 2006: 67). Tes yang diberikan pada siswa dalam penelitian berbentuk ganda dan esay, melalui tes ini akan memberikan gambaran tentang seberapa jauh pemahaman siswa dalam memahami konsep struktur atom. Hasil tes inilah yang kemudian akan digunakan sebagai acuan untuk menarik kesimpulan pada akhir penelitian.

\section{G. Teknik Analisa Data}

1. Analisis deskriptif

2. Uji Statistik

a) Uji varians

Hipotesis:

$\mathrm{H}_{0}=$ Tidak terdapat perbedaan hasil belajar menggunakan media pembelajaran kokami dengan ular tangga pada model pembelajaran langsung.

$\mathrm{H}_{1}=$ Terdapat perbedaan hasil belajar menggunakan media pembelajaran kokami dengan ular tangga pada model pembelajaran langsung 
b) Uji Normalitas

Kriteria pengujian

Jika sig > (0.05), maka $\mathrm{H}_{0}$ diterima.

Jika sig < (0.05), maka $\mathrm{H}_{0}$ ditolak

Uji parametrik (uji-t tidak berpasangan)

\section{HASIL PENELITIAN}

\section{A. Hasil Terakhir}

Tabel 1. Kualifikasi Kemampuan Akhir

\begin{tabular}{|c|c|c|c|c|c|}
\hline \multirow[b]{2}{*}{ Interval } & \multicolumn{4}{|c|}{ Frekuensi } & \multirow[t]{2}{*}{ Kualifikasi } \\
\hline & $\begin{array}{c}\text { Kelas } \\
\text { Eksperimen I } \\
\end{array}$ & $\%$ & $\begin{array}{c}\text { Kelas } \\
\text { Eksperimen II }\end{array}$ & $\%$ & \\
\hline $86-100$ & 11 & 33.33 & 7 & 21.21 & Sangat baik \\
\hline $76-85$ & 19 & 57.58 & 10 & 30.30 & Baik \\
\hline $73-75$ & 3 & 9.09 & 3 & 9.09 & Cukup \\
\hline$<73$ & - & - & 13 & 39.40 & Gagal \\
\hline Jumlah & 33 & 100 & 33 & 100 & \\
\hline
\end{tabular}

Setelah mengikuti proses pembelajaran, dilakukan tes berupa tes formatif (tes akhir) untuk mengetahui kemempuan akhir siswa. Tes akhir adalah tes yang digunakan untuk mengukur apakah siswa telat menguasai kompetensi tertentu seperti yang dirumuskan dalam indikator hasil belajar. Tes akhir dilakukan pada siswa menggunakan instrumen lembaran soal tes akhir berbentuk PG dan esay, sebanyak 10 soal. Hasil tes akhir yang ditunjukan pada tabel 4.8 terlihat bahwa pada kelas eksperimen I (Media pembelajaran kokami) sebanyak 11 siswa $(33,33 \%)$ berada pada kualifikasi sangat baik, 19 siswa (57,58\%) berada pada kualifikasi baik, dan 3 siswa $(9,09 \%)$ berada pada kualifikasi cukup dan tidak ada siswa yang berada pada kualifikasi gagal. Sedangkan pada kelas eksperimen II (Media pembelajaran ular tangga) sebanyak 7 siswa $(21,21 \%)$ siswa berada pada kualifikasi sangat baik, 10 siswa (30,30\%) berada pada kualifikasi baik, 3 siswa $(9,09 \%)$ berada pada kualifikasi cukup dan 13 siswa $(39,40 \%)$ berada pada kualifikasi gagal.

Hasil nilai akhir kelas eksperimen I menunjukan bahwa semua siswa (100\%) mencapai KKM, dengan data kualifikasi 11 siswa sangat baik, 19 siswa dengan kualifikasi baik dan 3 siswa dengan kualifikasi cukup. Hal ini disebabkan oleh media pembelajaran kokami yang memacu keingintahuan siswa sehingga berpengaruh terhadap prestasi siswa dalam setiap pertemuan dan meningkatkan pengetahuan sehingga siswa mampu mengerjakan soal tes akhir dengan baik, sejalan dengan penelitian Paisah Neneng, dkk (2012) tentang penerapan media kokami untuk peningkatan keterampilan berpikir kritis siswa yang menyimpulkan bahwa media ini dapat meningkatkan hasil belajar siswa. Pada tabel 1 juga terlihat 3 siswa berada pada kualifikasi cukup, ketiga siswa ini diketahui mempunyai nilai yang rendah pada aspek psikomotor maupun aspek afektif. Dari ketiga siswa ini, siswa dengan inisial E.T memiliki kemampuan yang lebih rendah namun terlihat media permainan kotak kartu misterius mampu membuat siswa ini termotivasi dan terus bertanya kepada guru sehingga siswa ini mampu menyelesaikan soal tes akhir dengan nilai yang mencapai KKM. Pada kelas eksperimen II, 20 siswa berhasil mencapai KKM, 7 siswa berada pada kualifikasi sangat baik, 10 siswa pada kualifikasi baik dan 3 siswa berada pada kualifikasi cukup. Hal ini menunjukan bahwa media ular tangga mempengaruhi prestasi siswa namun tidak semuanya siswa berada pada 
kualifikasi tersebut, pada tabel 1 terlihat 13 siswa berada pada kualifikasi gagal. Penyebab ketidaktutasan belajar siswa adalah kebiasaan belajar yang tidak terarah, kejenuhan belajar, belajar bilamana tes, tidak memiliki catatan yang lengkap, aspek afektif dan psikomotor yang rendah serta ketidaktarikan siswa untuk mengikuti proses pembelajaran. ketidaktuntasan siswa ini menunjukan bahwa pembelajaran menggunakan media belajar ular tangga pada penelitian ini belum efektif meningkatkan prestasi siswa dalam belajar.

\section{B. Uji Satistik}

\section{Uji Normalitas}

Hasil uji normalitas nilai tes akhir pada kedua kelas eksperimen dapat dilihat pada Tabel 2.

Tabel 2. Uji Normalitas Kolmogorov-Smirnova

\begin{tabular}{|rl|r|r|r|r|r|r|}
\hline & KELAS MIA 1 & \multicolumn{3}{c|}{ Kolmogorov-Smirnov } & \multicolumn{3}{c|}{ Shapiro-Wilk } \\
\cline { 2 - 7 } & dan 3 & Statistic & \multicolumn{1}{c|}{ Df } & \multicolumn{1}{c|}{ Sig. } & \multicolumn{1}{c|}{ Statistic } & \multicolumn{1}{c|}{ df } & Sig. \\
\hline \multirow{2}{*}{ NILAI AKHIR } & Kelas mia 1 & .239 & 33 & .000 & .875 & 33 & .001 \\
& Kelas mia 3 & .158 & 33 & .036 & .893 & 33 & .004 \\
\hline
\end{tabular}

Berdasarakan data yang diperoleh, nilai signifikansi untuk kelas eksperimen I adalah 0,001 (> $0,05)$ dan kelas eksperimen II yaitu 0,036 (> 0,05). Dengan demikian maka distribusi data kedua kelas eksperimen dikatakan tidak normal.

\section{Uji Homogenitas}

Data hasil uji homogenitas disajikan pada Tabel 3.

Tabel 3. Uji Homogenitas

\begin{tabular}{|c|c|c|c|}
\hline Levene Statistic & $\mathrm{df1}$ & $\mathrm{df2}$ & Sig. \\
\hline 12.680 & 1 & 66 & .001 \\
\hline
\end{tabular}

Berdasarkan data Tabel 3 terlihat bahwa nilai signifikansinya adalah $0,001(>0,05)$, ini menunjukkan bahwa data tes akhir kedua kelas eksperimen mempunyai varian yang berbeda. Dapat disimpulkan bahwa data tes akhir kedua kelas eksperimen adalah tidak homogen.

\section{Uji Mann - Whitney}

Data uji Mann-Whitney terhadap tes akhir siswa di antara kedua kelas eksperimen dapat dilihat pada Tabel 3.

Tabel 3. Uji Mann-Whitney Data Tes Akhir (Post-Test) Kedua Kelas Eksperimen Test Statisticsa

\begin{tabular}{|l|r|}
\hline & \multicolumn{1}{|c|}{ HasilBelajar IPA } \\
\hline Mann-Whitney U & 303,500 \\
Wilcoxon W & 864,500 \\
Z & $-3,117$ \\
Asymp. Sig. (2-tailed) &, 002 \\
\hline
\end{tabular}

a. Grouping Variable: Kelas 
Pada data uji Mann-Whitney, diperolah angka sig = 0,002 (sig < 0,05). Karena nilai sig $<0,05$, dapat di simpulkan bahwa terdapat perbedaan hasil belajar siswa kelas eksperimen I dan kelas eksperimen II pada konsep struktur atom.

Dalam pengujian data dengan menggunakan program SPSS dapat dilakukan uji parametrik dan uji nonparametrik. Salah satu jenis uji parametrik adalah uji-t tidak berpasangan. Uji-t tidak berpasangan dilakukan pada data yang diperoleh dari dua kelompok yang tidak berpasangan yang diberi perlakuan.

Hasil uji Mann-Whtiney (Tabel 4.11) diperoleh nilai sig =0,002 (sig<0,05). Berdasarkan hipotesis statistik $\mathrm{H}_{0}$ ditolak berarti $\mathrm{H}_{1}$ diterima dengan demikian, akhirnya perbedaan hasil belajar yang signifikan antara implementasi media pembelajaran kokami dan media ular tangga.

Pembelajaran yang dilakukan dengan penerapan media pembelajaran kokami lebih efektif dalam meningkatkan hasil belajar siswa dibandingkan pembelajaran yang dilakukan dengan penerapan media pembelajaran ular tangga. Dapat di buktikan dengan presentasi ketuntasan siswa dalam mengerjakan soal tes akhir, pada media kokami 100\% siswa berada pada kualifikai tuntas dengan nilai rata-rata 85.68 sedangkan pada kelas yang menggunakan media ular tangga, kualifikasi tuntas adalah $51.51 \%$ dan kualifukasi gagal $48.49 \%$ dengan nilai rata-rata 72.95 .

Dalam penelitian ini dapat dilihat bahwa keunggulan media kokami lebih menonjol sehingga dapat menutupi kekurang dari media pembelajaran ini, siswa lebih termotivasi dalam pembelajaran sehingga mampu memahami konsep yang diajarkan dibandingkan dengan kelas yang menggunakan media pembelajaran ular tangga, siswa cenderung ingin bermain dibandingkan menyatukan permainan dengan proses pembelajaran, salah satu kekurangan dari media ini adalah banyaknya peraturan yang harus di pahami siswa, jika siswa tidak serius dalam mengikuti proses pembelajaran maka akan dengan mudah siswa merasa bosan dan tidak termotivasi untuk memahami konsep yang diajarkan.

\section{KESIMPULAN}

Berdasarkan hasil penelitian, nilai rata-rata yang menggunakan media pembelajaran kotak kartu misterius adalah 85,68 sedangkan media ular tangga adalah 72,95 dan berdasarkan hasil uji hipotes, nilai signifikansinya adalah $0,002 \quad(<0,05)$ dengan demikian maka $\mathrm{H}_{0}$ ditolak sehingga dapat disimpulkan terdapat perbedaan hasil belajar siswa menggunakan media pembelajaran ular tangga.

\section{DAFTAR PUSTAKA}

Agus Suprijono. (2009). Cooperative Learning. Yogyakarta: Pustaka Pelajar.

Amir Indra kusuma, Daien. (1973). Pengantar IImu Pendidikan, (Surabaya: Usaha Nasional)

Arief S. Sadiman, dkk. (1996). Media Pendidikan Pengertian, Pengembangan, dan Pemanfaatannya. Jakarta: PT Raja Grafindo Persada.

Arief S. Sadiman, dkk. (2011). Media Pendidikan dan Proses Belajar Mengajar. Jakarta: PT Raja Grafindo Persada

Arsyad Azhar. (2011). Media pembelajaran. Jakarta: PT Raja Grafindo Persada.

Arikunto, Suharsimi. (2010). Prosedur Penelitian Suatu Pendekatan Praktek, Jakarta: Penerbit Rineka Cipta.

Arikunto, S. (2006) Prosedur Penelitian Suatu Pendekatan Praktik. Jakarta: Rineka Cipta.

Chang, R. (2005). Kimia konsep-konsep inti, Edisi ketiga jilid 1. Erlangga Jakarta

Dimyati dan Mudjiono. (2006). Belajar dan Pembelajaran. Jakarta: Rineka Cipta.

Djamarah, Syaiful Bahri dan Aswan Zain. (2010). Strategi Belajar Mengajar. Jakarta: PT Rineka Cipta. 
Depdikbud. (2013). Peraturan Menteri Pendidikan Dan Kebudayaan Nomor 81 A, 2013, Tentang Implementasi Kurikulum.

Depdikbud. (2007). Peraturan Menteri Pendidikan Nasional Republik Indonesia Nomor 24 Tahun 2007 Tentang Standar Sarana Dan Prasarana Untuk Sekolah Dasar/Madrasah Ibtidaiyah (Sd/Mi), Sekolah Menengah Pertama/Madrasah Tsanawiyah (Smp/Mts) Dan Sekolah Menengah Atas/Madrasah Aliyah (Sma/Ma) Aliyah (Sma/Ma).

Oemar Hamalik. (1982). Kesulitan-kesulitan Belajar. Bandung: Tarsito.

Oemar Hamalik. (2009). Proses Belajar-Mengajar. Bandung: bumi aksara.

Hakim. (2011). Media pengajaran kokami kotak dan kartu misterius. Jakarta. PT. RajaGraindo Persada.

Imron, Ali. (2012).Pendidikan Kesehatan Reproduksi Remaja. Ar Ruzz Media: Yogyakarta.

Istiqomah Febriana, Widiyatmoko Arif, Wusqo Urwatin Indah. (2016). Pengaruh media kokami terhadap keterampilan berpikir kreatif dan aktivitas belajar tema bahan kimia.Vol.5 No,2,1202-1212.

Kardi, S danNur, M. (2000). Pengajaran langsung. Dalam Trianto. (2011).Mendesain Model pembelajaran inovatif-progresif. Jakarta: Kencana

Ketut, E.S., Wayan, L.I., dan Wayan, S.I. (2013). Pengaruh Media CD Interaktif.

Khudori Mukh, Ashadi dan Masykuri M.(2012).Pembelajaran IPA dengan metode TGT menggunakan media games ular tangga dan puzzel ditinjau dari gaya belajar dan kreativ siswa.Jurnl inkuiri, Vol 1, No 11, 154-162.

Maria J Wantah. (2005). Pengembangan Disiplin dan Pembentukan Moral pada AnakUsiaDini. Jakarta: Departemen Pendidikan Nasional Direktoret

Leshin, C.B. dkk. (1992). Instructional design strategies and tactics. Englewood Cliffs: Educational Technology Publications.

Mulyasana, D. (2011). pendidikan bermutu dan budaya saing. Bandung: PT. Remaja Rosdakarya.

Paisah Neneng, Fatmayanti Desy Siska, \& Akhdiniwanto Wakhid, R. (2013). Penerapan media kotak dan kartu misterius (kokami) untuk peningkatan keterampilam berpikir kritis pada siswa kelas VII SMP Negeri 25 purorejo.Vol.3 No. 1, 28-31.

Pramita Amilia dan Agustini Rudiana.(2016).Pengembangan media permainan ular tangga pada materi senyawa hidrokarbon kelas xi sma untuk meningkatkan pemahaman konsep siswa. Unesa Journal of Chemical Education, Vol.5 No.2, 69-177.

Purnamawati Hening, Ashadi dan Susilowati Endang.(2004).Pengaruh model pembelajaran kooperatif tipe teams games tournament (tgt) dengan media kartu dan ular tangga ditinjau dari kemampuan analisis siswa terhadap prestasi belajar siswa pada materi pokok reaksi redoks kelas $\mathrm{x}$ semester 2 sma muhammadiyah 1 karanganyar tahun pelajaran 2013/2014.Jurnal pendidikan kimia. Vol.3 No.4, 100-108.

Rakhmadhani Nuzul, Yamtinah Sridan Utomo Bud Suryadi.(2013).Pengaruh penggunaan metode teams games tournaments berbantuan media teka - teki silang dan ular tangga dengan motivasi belajar terhadap prestasi siswa pada materi koloid kelas xi sma negeri 1 simo tahun pelajaran 2011/2012. Jurnal pendidikan kimia. Vol.2 No. 4 , 190-197.

Sanjaya. (2006). Strategi pebelajaran berorientasi standar proses pendidikan. Kencana prenada media group, Jakarta

Saputri, Novi. (2013). "Efektivitas Penggunaan Model Pembelajaran Jigsaw untuk Meningkatkan Hasil Belajar Akuntansi Kompetensi Dasar Dana Kas Kecil Siswa Kelas XI Akuntansi SMK Negeri 02 Pekalongan. Skripsi. Universitas Negeri Semarang

Slameto. (2003). Belajar dan Faktor-Faktor yang Mempengaruhinya. Jakarta: PT Asdi Mahasatya.

Sri Rahayu Ningsih, Tine Maria Kuswati, Elly Marati, Sukardjo. (2013). Kimia Sma/Ma kelas X. Jakarta. PT Bumi Aksara.

Sudjana (2009). Dasar- dasar proses belajar mengajar. Bandung: sinar baru Algesindo

Sudjana, Nana dan Rivai. (2005). Teknologi Pengajaran. Bandung: Sinar Baru Algesindo 
Sudjana, Nana, Rivai, Ahmad. (2007). Teknologi Pengajaran. Bandung: Sinar baru Algensindo. Sudijono, Anas. (2006). Pengantar Evaluasi Pendidikan, Jakarta: Raja Grafindo persada Sugiharti P. (2005). Penerapan teori multiple intelegence dalam pembelajaran fisika. Jurnal Pendidikan Penabur 4 (5):29-42

Suryosubroto. (2009). Proses Belajar Mengajar di sekolah. Jakarta: PT Rineka Cipta.

Suyanti, Retno Dwi. (2010). Strategi pembelajaran kimia. Yogyakarta: Graha Ilmu

Trianto. (2011).Model-model pembelajaran inovatif berorientasi konstruktivitis. Jakarta:Prestasi Pustaka

Umar Titarahardja dan S.L. La Sulo. (2010). Pengantar Pendidikan. Jakarta: PT Asdi Mahasatya.

Widaningsih, Dedeh. (2010). Perencanaan Pembelajaran matematika. Bandung: Rizqi Press 